\title{
Pulay Gyula
}

\section{Az integritásirányítás lehetséges modelljei}

\author{
The potential models of integrity management
}

\begin{abstract}
Absztrakt
Egy szervezet az integritásirányítás milyen modelljét alkalmazva képes leginkább elérni, hogy dolgozói minden körülmények között a szervezeti értékrendnek megfelelő döntéseket hozzanak? - erre a kérdésre keresi a cikk a választ. A modelleket egyrészt aszerint csoportosítja, hogy az integritásirányítási rendszer miként kapcsolódik a belső kontrollrendszerhez, másrészt megkülönbözteti a modelleket aszerint, hogy a szervezeti kultúra mennyire mozdult el a szabályalapúságtól a küldetésvezérelt és a hivatástámogató értékkövetés irányába. A cikk felvázol több lehetséges modellt, ismertetve lényeges tulajdonságaikat és célszerü alkalmazási területüket.
\end{abstract}

Kulcsszavak: integritás, integritásirányítás, belső kontrollrendszer, szervezeti kultúra, modellek

\begin{abstract}
What model of integrity management can an organization best use to ensure that its employees make decisions that are consistent with organizational values in all circumstances? - the article is looking for the answer to this question. On the one hand, it groups the models according to how the integrity management system is related to the internal control system. On the other hand, it distinguishes models according to the extent to which organizational culture has shifted from rule-based to the two types of value-based culture, one is the mission driven, the second supports the fulfilment of the profession (vocation) of its employees. The article outlines several possible models, describing their essential properties and the area where the models can be used expediently.
\end{abstract}

Keywords: integrity, integrity management, internal control system, organizational culture, models 


\section{Bevezetés}

Évek óta foglalkoztat a kérdés, hogy a szervezeti integritás megteremtésének és megszilárdításának milyen sikeres modelljei vannak vagy lehetnek. A kérdésre elsősorban abból a szempontból kerestem a választ, hogy a szervezet milyen modell mentén haladva képes leginkább elérni azt, hogy dolgozói minden körülmények között a szervezeti értékrendnek megfelelö döntéseket hozzanak. Kutatásomnak különös aktualitást adott a Kormány 1328/2020. (VI. 19.) Korm. határozata a 2020-2022 közötti időszakra szóló középtávú Nemzeti Korrupcióellenes Stratégia, valamint az ahhoz kapcsolódó intézkedési terv elfogadásáról. Az intézkedési terv 13. pontja felszólítja a belügyminisztert, hogy ,a közszféra integritásának továbbfejlesztése érdekében - az államigazgatási szervek integritásirányitási rendszere müködési tapasztalatainak felhasználásával-vizsgálja meg [...] milyen integritásirányítási modell alkalmazása lenne célszerü a különféle ágazatokba és szervtípusokba tartozó költségvetési szervek, valamint az állam többségi befolyása alatt álló gazdasági társaságok esetében".

E cikkben az alábbi kérdésekre keresem a választ:

- Mit értünk integritásirányítási modell alatt?

- Milyen jellemzők szerint célszerü ezeket egymástól megkülönböztetni?

\section{Integritási modellek}

A jog-, a közigazgatás- és a rendészettudomány müvelői is rendszeresen felállítanak modelleket. A szervezeti integritásnak is különböző modelljeit dolgozták már ki (Lander \& Nahon, 2006; Boland, 2015). Következésképpen célszerünek látszik az integritásirányítás kutatásánál is modelleket alkalmazni. A tudományos modelleknek számos definícióját találhatjuk a különböző tudományágak szakirodalmában. Ezek figyelembevételével saját kutatásom során a modell fogalmát a következőképpen határozom meg: a modell egy bonyolult rendszer egyszerüsített megjelenítése, ami csak a vizsgált kérdés szempontjából lényeges vonásokat emeli ki, ide értve azokat a jellemzőket, amelyek megkülönböztetik az adott modellt a hasonló funkciót ellátó más modellektől.

A szervezeti integritásnak a Gazdasági Együttmüködési és Fejlesztési Szervezet (a továbbiakban: OECD) által a közszférára kidolgozott modelljét az 1. számú ábra szemlélteti. Az OECD szerint az egyes országok közszférája integritásának érettségét aszerint lehet vizsgálni, hogy e modell egyes elemei menynyire épültek ki, illetve ténylegesen müködnek-e (OECD, 2017). 


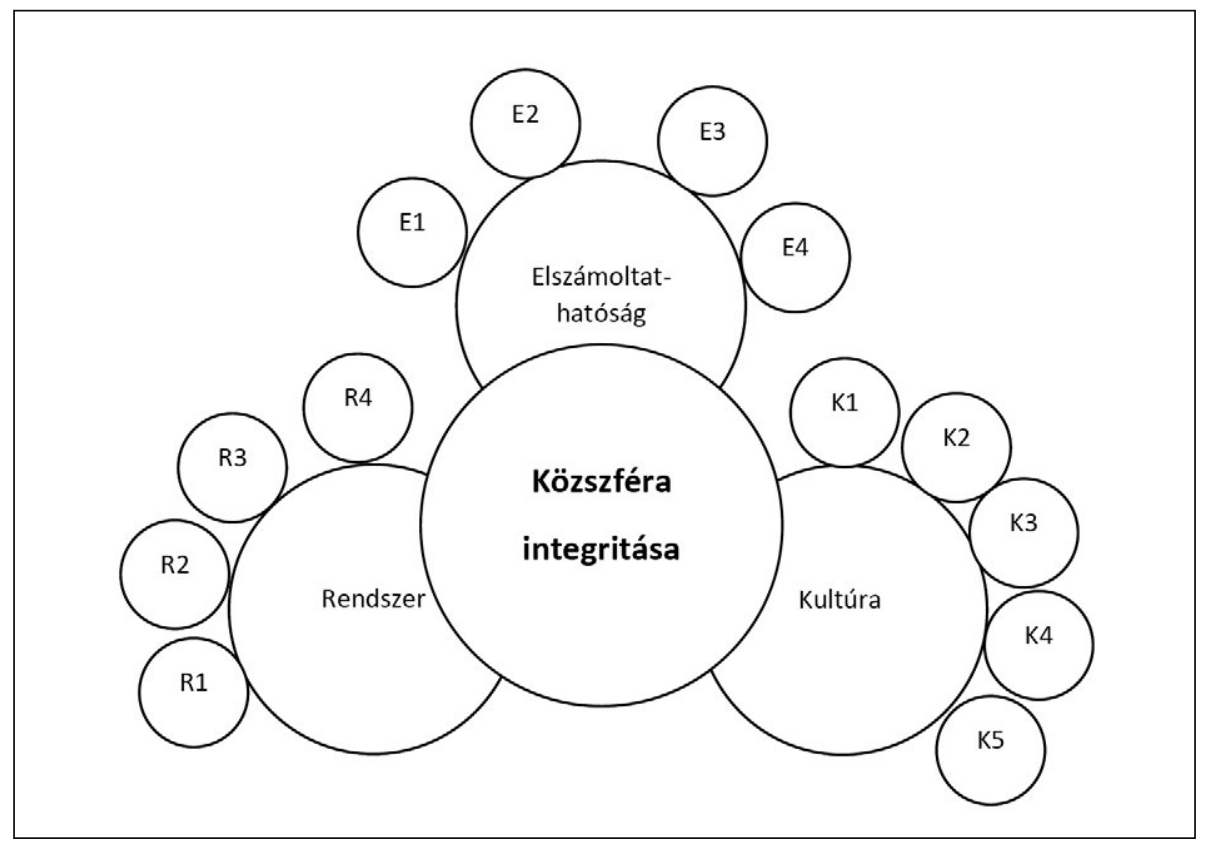

Forrás: OECD, 2017 alapján a szerző saját szerkesztése.

Mint látható a modell a közszféra szervezeti integritásának három pillérét emeli ki, és azokhoz további elemeket rendel. Ezek a következők:

- R1: Elköteleződés. R2: Felelősségek. R3: Stratégia. R4: Sztenderdek.

- E1: Kockázatkezelés. E2: Kikényszerítés. E3: Felügyelet. E4: Részvétel.

- K1: Össztársadalmi támogatottság. K2: Vezetés. K3: Érdemalapúság. K4: Kapacitásfejlesztés. K5: Nyitottság.

Integritásmodellnek tekinthető az EUROSAI ${ }^{1}$ Etika és Audit Munkacsoportja által kidolgozott keretrendszer, amelyet a 2. számú ábra szemléltet. A modellek részletes ismertetése meghaladná e cikk kereteit. Mondanivalóm szempontjából azt tartom lényegesnek, hogy mindkét modellben kiemelt jelentőségü a szervezeti kultúra, és annak illeszkedése a rendszer, illetve a szabályozás egészéhez. A továbbiakban e cikk is aszerint különbözteti meg a szervezeti integritás modelljeit, hogy azok miként illeszkednek a szervezet szabályozási (irányítási) rendszeréhez, illetve a szervezeti kultúra mely vonatkozásait teszik hangsúlyossá.

1 A Legfőbb Ellenőrző Intézmények Nemzetközi Szervezete (INTOSAI) európai regionális szervezete. 
2. számú ábra: A szervezeti integritás szintjei

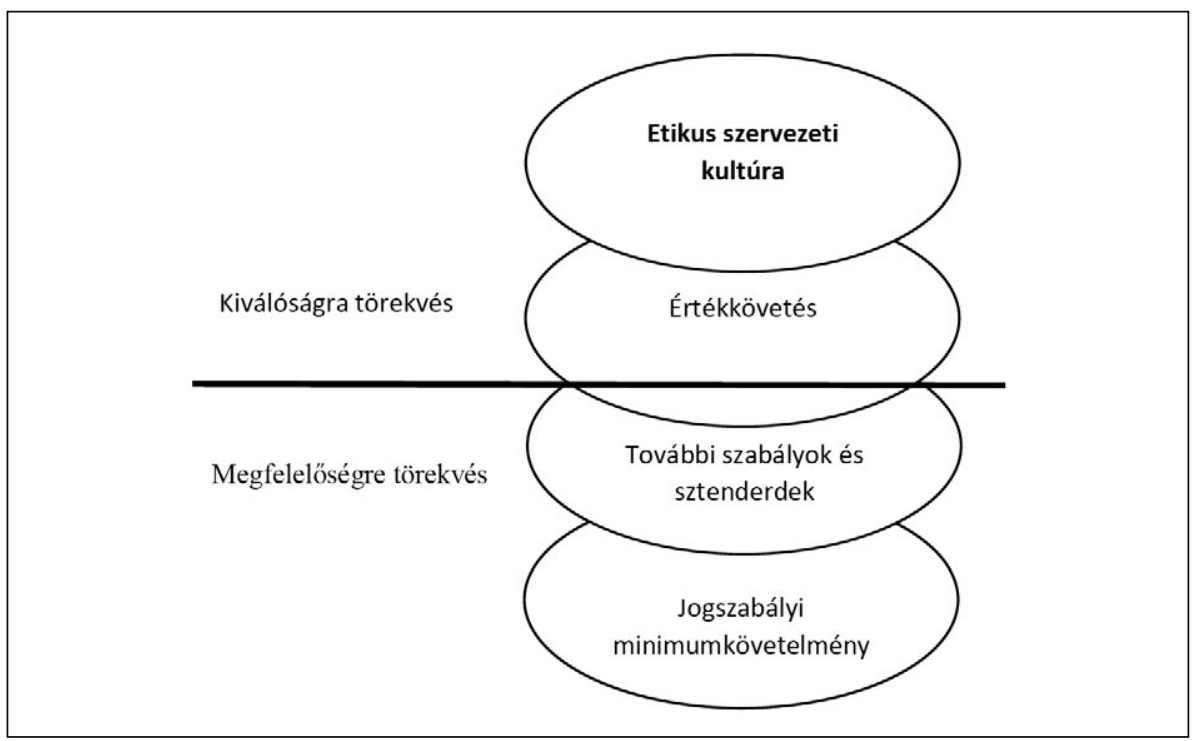

Forrás: EUROSAI TF\&E (URL1) alapján a szerző saját szerkesztése.

\section{Az államigazgatási szervek integritásirányítási rendszere mint alapmodell}

A hivatkozott kormányhatározat elöírja, hogy „az államigazgatási szervek integritásirányitási rendszere müködési tapasztalatainak felhasználásával" kell a célszerüen alkalmazható integritásirányítási modelleket kiválasztani. Ezért e cikk kiinduló pontja is ez az integritásirányítási rendszer, amelynek a szabályait az államigazgatási szervek integritásirányítási rendszeréről és az érdekérvényesítők fogadásának rendjéről szóló 50/2013. (II. 25.) Korm. rendelet (a továbbiakban: Intr.) fektette le.

Az Intr. 2. § b) pontja az integritásirányítási rendszer fogalmát a következőképpen határozza meg: , az irányitási és vezetési rendszer funkcionális alrendszere, amely az államigazgatási szerv integritás alapú müködésének megteremtésében részt vevö személyek és csoportok tevékenységének összehangolásával, a költségvetési szervek belső kontrollrendszeréröl és belsö ellenörzéséröl szóló 370/2011. (XII. 31.) Korm. rendelet (a továbbiakban: Bkr.) szerinti kontrollkörnyezethez illeszkedve biztositja a szervezeti kultúra egységét az értékek, elvek, célkitüzések és szabályok meghatározása, a követésükhöz szükséges útmutatás és tanácsadás, a megfelelés nyomon követése és szükség esetén kikényszeritése útján". 
Az Intr. a modell szót nem használja, magából a definícióból azonban ki lehet emelni olyan elemeket, amelyek a különböző integritásirányítási modellek megkülönböztető jellemzői lehetnek. A kiemelés során célszerü tekintetbe venni az integritásnak az Intr. szerinti definícióját: „2. § a) integritás: az államigazgatási szerv szabályszerü, a hivatali szervezet vezetöje és az irányitó szerv által meghatározott célkitüzéseknek, értékeknek és elveknek megfelelö müködése". E definíció megfogalmazásakor a rendelet alkotói figyelembe vették azt - az EUROSAI TF\&E modellben is tükröződő - tudományos megközelítést, amely szerint a szervezeti integritásnak két szintje van: az alapszint a szabálykövetés, és erre épül rá az értékkövetés szintje.

Egy szervezet szabályos müködését és céljainak elérését elősegítő, illetve kikényszerítő szervezetirányítási rendszernek számos változatát kidolgozták már az elmúlt évtizedekben, és ezeket széles körben alkalmazzák a gyakorlatban is. Az újdonságot a második szint jelenti, vagyis az, hogy miként lehet az értékeknek és elveknek megfelelő működést elősegíteni és kikényszeríteni. Emellett fontos kérdés az is, hogy a két szintet miként lehet harmonikusan egymáshoz illeszteni. Ez részben függ attól, hogy a külső szabályozás (a jogszabályok, az irányító szervi vagy tulajdonosi döntések) mire kötelezik a szervezetet, részben pedig attól, hogy maga a szervezet milyen eszközökkel próbálja előmozdítani dolgozói értékkövető magatartását.

A fenti megfontolások alapján az integritásirányítási modellre az alábbi definíciót adom: Az integritásirányítási modell annak a megjelenítése, hogy egy szervezet belső és külső szabályozási környezete miként segíti elő a szervezet értékeknek és elveknek megfelelő müködését, és azt hogyan kapcsolja össze a szabályos müködés követelményével.

\section{Az integritásirányítási rendszer modellalkotó jellemzői}

Az integritásirányítási rendszer Intr. szerinti definíciójának melyek azok az elemei, amelyek a különböző szervezeti típusok esetében más formát ölthetnek, és így egy új modell szempontjából választóvonalul szolgálhatnak? E kérdés megválaszolása érdekében felbontom a definíciót nagyobb egységekre. Az integritásirányítási rendszer

- az irányítási és vezetési rendszer funkcionális alrendszere, amely a szervezet integritásalapú müködésének megteremtését szolgálja. Felvetődhet az ötlet, hogy az integritásirányítási rendszert ne az irányítási és vezetési rendszer funkcionális alrendszereként, hanem egy teljesen önálló rendszerként határozzuk meg. Ezt nem tartom célszerünek, mivel ez esetben az 
értékkövetés elősegítését szolgáló rendszerelemeket kiszakítanánk a szabályos müködés biztosítására hivatott rendszerből. Ezt az eshetőséget a továbbiakban nem vizsgálom.

- az integritás megteremtésében résztvevő személyek és csoportok tevékenységét összehangolja. Az összehangolás nagyon különböző módon valósulhat meg, így ez modellképző ismérv lehet.

- a kontrollkörnyezethez illeszkedik. A belső kontrollrendszer jogszabályi meghatározása olyan külső szabályozási körülmény, amely az alkalmazható modellt alapjaiban érinti. Nem magától értetődő, hogy a kontrollkörnyezet az, ahol az integritásirányítási rendszer optimálisan illeszkedik a belső kontrollrendszerhez. Több, modellszerủen különböző megoldás is létezhet.

- biztosítja a szervezeti kultúra egységét. Modellképző jellemző lehet, hogy mi a tartalma annak a szervezeti kultúrának, amelynek az egységét az integritásirányítás biztosítani hivatott.

A felsoroltak közül két olyan ismérvet választottam ki, amelyek alapján a különböző integritásirányítási modelleket egymástól meg lehet különböztetni, illetve újabb modelleket lehet alkotni:

- Az integritásirányítási rendszer milyen módon illeszkedik a belső kontrollrendszerhez?

- Melyek a fö tartalmi jegyei annak a szervezeti kultúrának, amelynek az egységességét az integritásirányítási rendszer megerősíteni hivatott?

\section{Az integritásirányítási rendszer illeszkedése a belső kontrollrendszerhez mint modellképzési tényező}

A költségvetési szervek belső kontrollrendszerét részletesen a Bkr. szabályozza. Jogszabály meghatározhatja azt is, hogy az integritásirányítási rendszer miként illeszkedjen a belső kontrollrendszer öt pillérhez:

- a kontrollkörnyezethez,

- az (integrált) kockázatkezeléshez,

- a kontrolltevékenységekhez,

- az információs és kommunikációs rendszerhez, valamint

- a nyomon követéshez (monitoringhoz).

2013-ban, az Intr. kihirdetésekor erre nem került sor. Néhány év múlva a jogalkotó célszerünek tartotta e kérdéskör jogszabályi rendezését, valószínüleg azért, mert akkorra már minden költségvetési szervvel szemben követelménnyé vált 
a szervezeti integritásra törekvés. A megfogalmazás miszerint az államigazgatási szervek integritásirányítási alrendszere a szervezet belső kontrollrendszere kontrollkörnyezetéhez illeszkedik, az Intr. 2016. évi módosítása során került be a rendelet szövegébe. Az e módosítást hozó kormányrendelet ${ }^{2}$ egyúttal módosította a Bkr.-t is, és abba számos olyan elemet épített be, amelyek a költségvetési szervek integritásának megszilárdítását segítik elő. Ugyanakkor a Bkr. az „integritásirányítási rendszer” kifejezést nem használja.

\section{Illeszkedés a kontrollkörnyezeten keresztül - a költségvetési szervek modellje}

A hivatkozott módosítás révén a Bkr. kontrollkörnyezetet szabályozó paragrafusa több, a szervezeti integritás megteremtésére, illetve megerősítésére hivatott kötelezettséget is megállapít. A költségvetési szerv vezetője köteles

- olyan kontrollkörnyezetet kialakítani, amelyben meghatározottak, ismertek és elfogadottak az etikai elvárások a szervezet minden szintjén, valamint biztosított a szervezeti célok és értékek irányában való elkötelezettség fejlesztése és elősegítése.

- szabályozni a szervezeti integritást sértő események kezelésének eljárásrendjét, valamint az integrált kockázatkezelés eljárásrendjét.

- olyan belső kontrollrendszert kialakítani, amely minden tevékenységi kör esetében alkalmas az etikai értékek és az integritás érvényesítésének biztosítására.

A fentiek alátámasztják, hogy a Bkr. szerinti szabályozásban az integritásirányítási rendszer elsősorban a kontrollkörnyezethez illeszkedve kapcsolódik a belső kontrollrendszerhez. Az integritásra törekvést a módosító rendelet más pillérek szabályozásába is beépítette, azáltal, hogy bevezette az integrált kockázatkezelési rendszer fogalmát, amely a szervezet értékeit fenyegető kockázatokra is kiterjed. A Bkr. kontrolltevékenységeket felsoroló rendelkezése pedig kiegészült a szervezet integritását erősítő kontrolltevékenységekkel. Ugyanakkor a Bkr. információs és kommunikációs rendszert, illetve a nyomon követést szabályozó paragrafusai még utalást sem tartalmaznak az integritásra. A jogszabályi szövegből kiolvasható szervezeti integritási modellt a 3. számú ábra szemlélteti.

2 187/2016. (VII.13) Korm. rendelet egyes kormányrendeleteknek a belső kontrollrendszer és az integritásirányítási rendszer fejlesztésével összefüggő módosításáról. 
3. számú ábra: Az integritásirányitási rendszer illeszkedése a belsö kontrollrendszerhez a Bkr. szabályai szerint

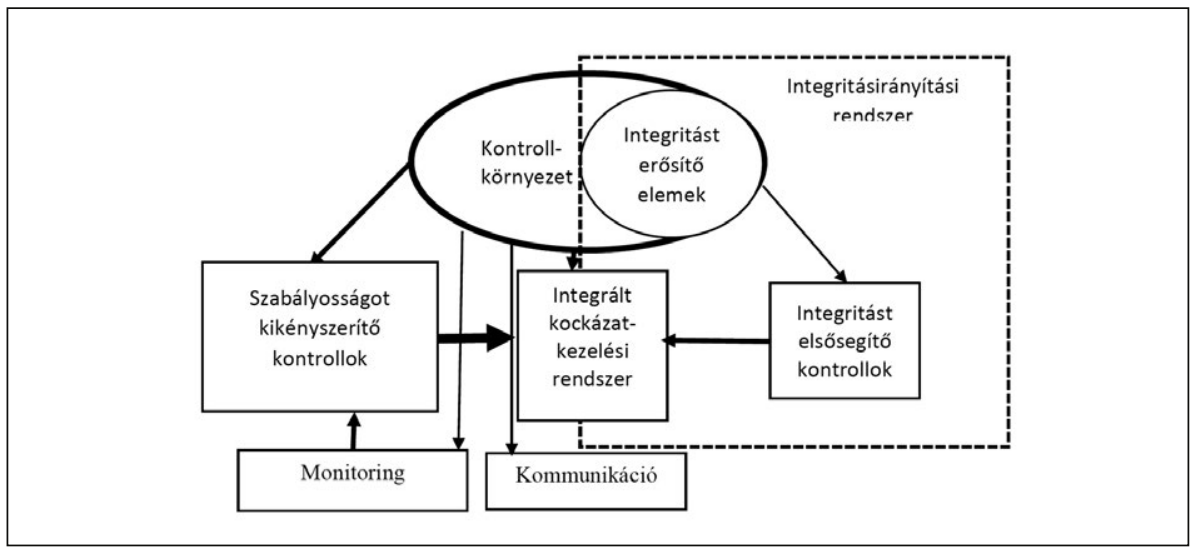

Forrás: A szerző saját szerkesztése.

\section{Illeszkedés a belső kontrollrendszer minden pillérén keresztül - a köztulajdonú gazdasági társaságok modellje}

2020-tól kezdve a köztulajdonban álló gazdasági társaságok ${ }^{3}$ számára is törvény ${ }^{4}$ tette kötelezővé a kormányrendeletben szabályozott belső kontrollrendszer kialakítását és müködtetését. A 339/2019. (XII. 23.) Korm. rendelet a köztulajdonban álló gazdasági társaságok belső kontrollrendszeréről (a továbbiakban: Gtbkr.) a Bkr. integritással összefüggő rendelkezéseit átvette, de azokon túlmutató szabályokat is megállapít. A Gtbkr. 7. § (2) bekezdése arra kötelezi a társaság vezetöjét, hogy a szervezeti integritást sértő események és panaszok bejelentése és kezelése érdekében bejelentőrendszert alakítson ki és működtessen. Ezáltal a belső kontrollrendszer információs és kommunikációs rendszer pillérében is megjelent egy nagyon fontos integritási elem.

A Gtbkr. 9. § (1) bekezdése előírja, hogy a társaság vezetője megfelelést támogató szervezeti egységet hozzon létre. A 10. § (1) bekezdés ezen egység feladatává teszi a társaság értékeinek és elveinek való megfelelés nyomon követését is. Ezáltal a belső kontrollrendszer ötödik pillérének részévé vált az integritás megvalósulásának nyomon követése. A vezető ezen egységet meghatalmazhatja a társaság müködésével összefüggő integritást sértő bejelentések fogadásával és

3 Kivéve a kisebb méretű társaságokat, és néhány a törvényben nevesített társaságot.

4 2009. évi CXXII. törvény a köztulajdonban álló gazdasági társaságok takarékosabb müködéséröl. 
kivizsgálásával kapcsolatos feladatok ellátásával is. Az integritási elem bekerült a monitoring rendszer másik területének, a belső ellenőrzésnek a feladatai közé is, mivel a Gtbkr. 14. § (2) bekezdése értelmében a belső ellenőr bizonyosságot adó tevékenysége körében elemzi, vizsgálja és értékeli az etikai elvárások és értékek érvényesülésének elősegítését is.

A hivatkozott rendelkezések révén a köztulajdonú gazdasági társaságok belső kontrollrendszerének minden pillére tartalmaz a szervezeti integritás megteremtésére és megerősítésére hivatott elemet. Következésképpen az integritásirányítási rendszer már nemcsak a kontrollkörnyezeten keresztül illeszkedik a belső kontrollrendszerhez, hanem a kapcsolódás minden pillér esetében megtörténik. Sőt, a kockázatkezelés és a nyomon követés (monitoring) esetében többröl van szó puszta illeszkedésnél, itt a szabályközpontú és az értékközpontú megközelítést integráltan kell alkalmazni. Ezt a modellt a 4. számú ábra szemlélteti.

\section{4. számú ábra: A belső kontrollrendszerbe integrált integritásirányítási rendszer modellje}

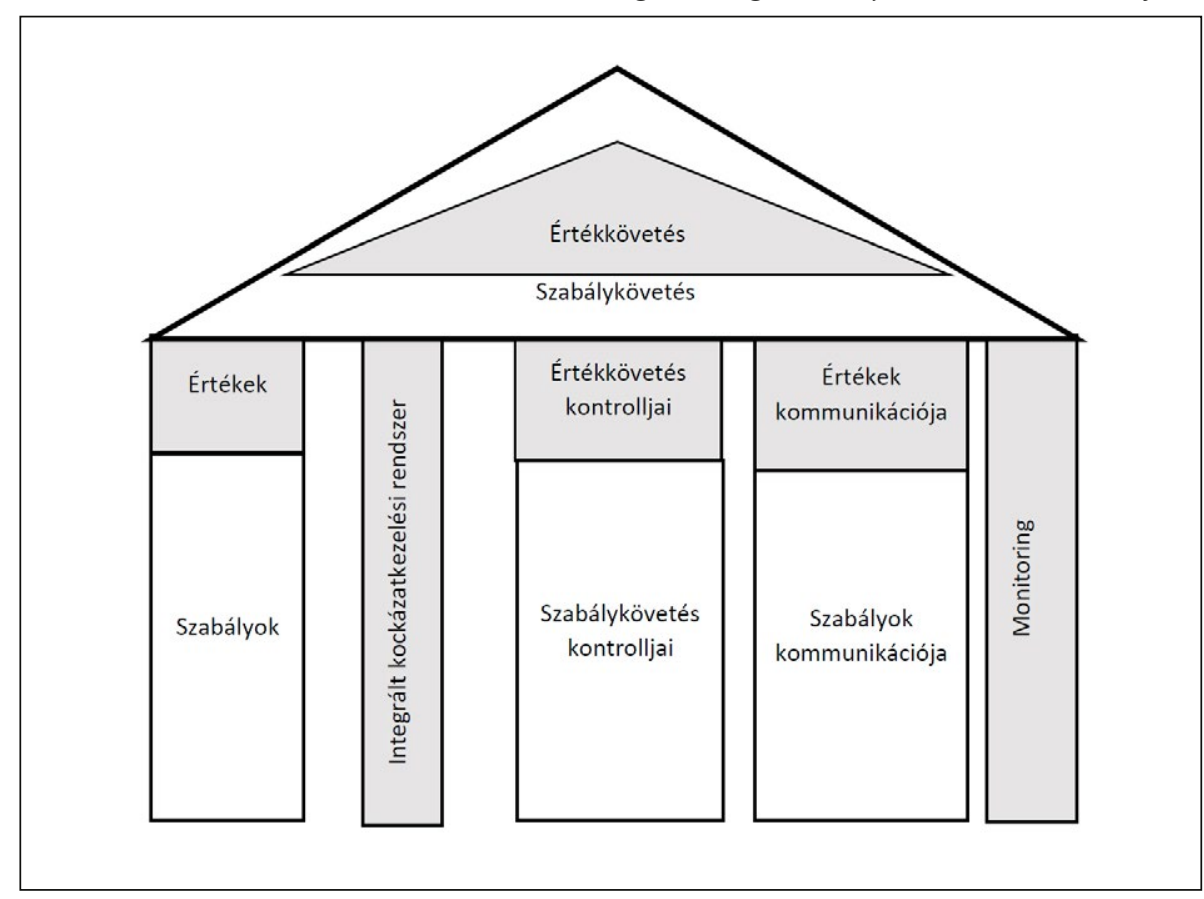

Forrás: A szerző saját szerkesztése.

Az ábra érzékelteti, hogy e modellben a hangsúly már nem az elkülönülésen van, hanem azon, hogy a szervezet müködésében a szabálykövetés és az értékkövetés egyaránt érvényesüljön. Az ábrán az integritásirányítási rendszer 
elemeit szürke szín jelzi. Látható, hogy három pillér esetében megmarad ezek viszonylagos önállósága, a kockázatkezelés és a monitoring esetében azonban a nagyobb szinergia érdekében célszerü közös megoldásokat alkalmazni. (Ez nem jelenti azt, hogy a kockázatkezelésben vagy a nyomon követésben ne kellene az integritás sajátosságait figyelembe venni.) Az ábra azt is kifejezi, hogy az értékkövetés a szabálykövetésre épül, de semmiképpen sem váltja ki azt.

A valamennyi pilléren keresztül illeszkedő modell áll a legközelebb az integritásirányítási rendszer OECD által kidolgozott modelljéhez, amely két szintet és három pillért tartalmaz (OECD, 2009). A felső szintet az integritás magintézkedései jelentik, vagyis azok a kontrollok, amelyeket kifejezetten a szervezeti integritás erősítése érdekében hoztak létre (például etikai kódex, ünnepélyes eskütétel). Az alsó szinten helyezkednek el az integritás kiegészítő intézkedései, azok a kontrollok, amelyeket más szakpolitikák alkalmaznak, de jelentós a szerepük az integritás erősítésében (például a munkaerő kiválasztásának vagy a közbeszerzéseknek a kontrolljai). A három pillért az eszközök, a folyamatok és a struktúrák alkotják. Ily módon az integritásirányítási rendszer egy emeletes házra hasonlít, amelyben a szervezet kontrollrendszere alkotta földszintre épül rá az integritásirányítás saját szintje, és a két szint három pilléreken keresztül kapcsolódik egymáshoz. Nem véletlen, hogy az OECD tanulmányának címében a szilárd integritás kifejezés szerepel.

\section{Illeszkedés a kockázatkezelésen keresztül - a holland modell}

Figyelemre méltó a holland központi közigazgatásban alkalmazott - a magyar közszféra integritási kultúrája megteremtésében sok szempontból mintaadó integritásirányítási rendszer, amely a kockázatkezelésen keresztül kapcsolódik a szervezeti irányítás rendszeréhez. E megközelítés lényege az, hogy a közigazgatási szerv integritását különböző kockázatok fenyegetik, és ezek elhárítása, illetve csökkentése érdekében többféle intézkedést is alkalmazni lehet. A holland rendszer megkülönböztet „kemény”, „lágy” és ,általános” intézkedéseket, és ezeket összesen 14 csoportba sorolja (1. számú táblázat). 
1. számú táblázat: Az integritásirányitási intézkedések csoportjai a holland közigazgatásban

\begin{tabular}{|l|l|l|}
\hline \multicolumn{1}{|c|}{ Kemény intézkedések } & \multicolumn{1}{|c|}{ Lágy intézkedések } & Általános intézkedések \\
\hline $\begin{array}{l}\text { 1. Jogszabályok és egyéb } \\
\text { szabályok }\end{array}$ & 5. Értékek, normák kinyilvánítása & $\begin{array}{l}\text { 9. Új alkalmazottak felvétele és } \\
\text { kiválasztása }\end{array}$ \\
\hline $\begin{array}{l}\text { 2. Felelösségi körök } \\
\text { meghatározása }\end{array}$ & $\begin{array}{l}\text { 6. Integritással kapcsolatos } \\
\text { tudatosság }\end{array}$ & $\begin{array}{l}\text { 10. Integritással kapcsolatos } \\
\text { szabálysértések kezelése }\end{array}$ \\
\hline $\begin{array}{l}\text { 3. Hivatali szervezet/ } \\
\text { belső kontrollok }\end{array}$ & 7. Vezetés hozzáállása & 11. Szabályozási keret \\
\hline 4. Biztonság & 8. Szervezeti kultúra & $\begin{array}{l}\text { 12. Veszélyeztetettség/ } \\
\text { kockázatelemzés }\end{array}$ \\
\hline & & 13 Elszámolási kötelezettség \\
\hline
\end{tabular}

Forrás: Báger, Korbuly \& Pulay (2008) alapján a szerző saját szerkesztése.

„Kemény” intézkedésnek azokat a kontrollokat tekintik, amelyek közvetlen hatnak a dolgozók viselkedésére, azaz konkrét tiltást vagy felszólítást tartalmaznak. A ,lágy” intézkedések közvetetten - az emberek gondolkodásának, értékítéleteinek, jellemének alakításán keresztül befolyásolják a dolgozók magatartását. Az ,általános” intézkedések az előbbi két intézkedéstípus alkalmazásának kereteit teremtik meg. Ez a megközelítés arra hívja fel a figyelmet, hogy az értékkövetést nem lehet csak „lágy” kontrollokkal előmozdítani, hanem szükség van a kockázatkezelés kereteit megteremtő általános kontrollokra, és a helytelen magatartást megelőző, vagy akár a helyes cselekvést kikényszerítő „,kemény" intézkedésekre is. Ezen a ponton a holland modell és az OECD modell (lásd az 1. számú ábrát) találkozik egymással, mivel az utóbbi is magában foglal „kemény” kontrollokat (például összeférhetetlenség kizárása, elszámoltathatóság, felülvigyázat) is.

A kockázatközpontú megközelítés gyökeret vert a magyar integritásirányításban is, éppen az államigazgatási szervek esetében. Az Intr. ugyanis elöírja, hogy hatálya alá tartozó szervezetek vezetőinek évente fel kell mérniük az államigazgatási szerv müködésével kapcsolatos integritási és korrupciós kockázatokat, és a felmérés alapján egyéves intézkedési tervet kell megfogalmazniuk a kockázatok kezelésére. A terv végrehajtását és annak eredményeit a vezetőnek integritásjelentésben kell összefoglalnia, és meg kell küldeni az illetékes miniszterek számára. Következésképpen az integritásirányítási rendszernek ez a leghangsúlyosabb eleme, és fontos illeszkedési pontja a kontrollrendszer egészéhez. 


\section{A szervezeti kultúra mint modellképző tényező}

Az Intr. hivatkozott definíciója szerint az integritásirányítási rendszer funkciója a szervezeti kultúra egységének biztosítása. Milyen legyen az a szervezeti kultúra, amelynek egységességét az integritásirányítási rendszer biztosítani hivatott? Az integritás lényegéből adódóan a szervezeti kultúrák lehetséges változatait első körben aszerint célszerủ megkülönböztetni, hogy azok mennyire szabályalapúak, illetve mennyire támaszkodnak az értékkövetésre. A legtöbb szervezetnél jelen van a szabályalapú és az értékközpontú megközelítés is, ezért a kettőt nem célszerü egymással szembeállítani. Sokkal inkább egy olyan mérörudat célszerü elképzelnünk, amelynek egyik végpontja a tisztán szabályalapú, a másik végpontja a tisztán értékkövető szervezeti kultúra, a valóságos szervezeti kultúrák pedig a két végpont között helyezkednek el.

Második körben a szervezeti kultúrákat aszerint lehet osztályozni, hogy az értékkövetés során a szervezet küldetését helyezik előtérbe, vagy alkalmazottaikat hozzák abba a helyzetbe, hogy személyes hivatásukat ki tudják bontakoztatni. Egyes foglalkozásokat a közvélekedés hivatásnak tekint, és a hivatást választók többsége a hivatás értékeinek vonzásában hozza meg döntését, azaz eleve értékeket szeretne követni: gyógyítani szeretne, tehetségeket szeretne kibontakoztatni, a hazáját szeretné hősiesen védeni. Esetükben a szervezet az önvezérlésre építhet, és fó feladata a hivatás kibontakozásának támogatása. A szervezeti kultúrának ezt a típusát hivatástámogató kultúrának nevezem.

Sok munkakörnek nincs önmagán túlmutató értékkészlete, mivel alapjában véve dolgokat állítanak elö, egy gépezet kis csavarját jelentik. Az ilyen munkakörben dolgozók számára munkáltatójuknak kell olyan küldetést megfogalmazni, amelynek követése esetén értékesebbnek érezhetik magukat. Például „mi állítjuk elő a legbiztonságosabb autókat”, „mi gondoskodunk városunk tisztaságáról”. Emellett olyan értékeket kell a dolgozók elé állítani, amivel ők személyesen azonosulni tudnak, és így azokat majd önként is követik. E szervezeti kultúratípust küldetésvezéreltnek nevezem. A két típusú kultúra nem áll mereven szemben egymással, ahogy a foglalkozásokat sem lehet egyértelmủen elkülöníteni aszerint, hogy melyik hivatás és melyik puszta pénzkereseti lehetőség. Sok esetben a komoly hivatástudattal rendelkező emberek erős küldetésü szervezetnél dolgoznak, ahol a dolgozó hivatása és a szervezet küldetése egymást erősíti. Valójában a szervezet küldetése és alkalmazottainak hivatása nem két szembenálló fogalom, hanem a szervezeti kultúra két lehetséges dimenziója.

A fentiekkel összhangban az 5. számú ábra a szervezeti kultúrák lehetséges modelljeit olyan koordináta rendszerbe helyezi el, amelynek origójában a tisztán szabályalapú szervezeti kultúra található. A vízszintes tengely értékei azt 
jelzik, hogy ettől az állapottól a szervezi kultúra mennyire mozdult el a küldetésvezérelt kultúrák felé, a függőleges tengely értékei pedig azt mutatják, hogy a szervezet kultúrája mennyire épít a dolgozók hivatástudatára, és mennyire támogatja azt.

5. számú ábra: Integritásirányitási modellek típusai a szervezeti kultúra két dimenziója mentén

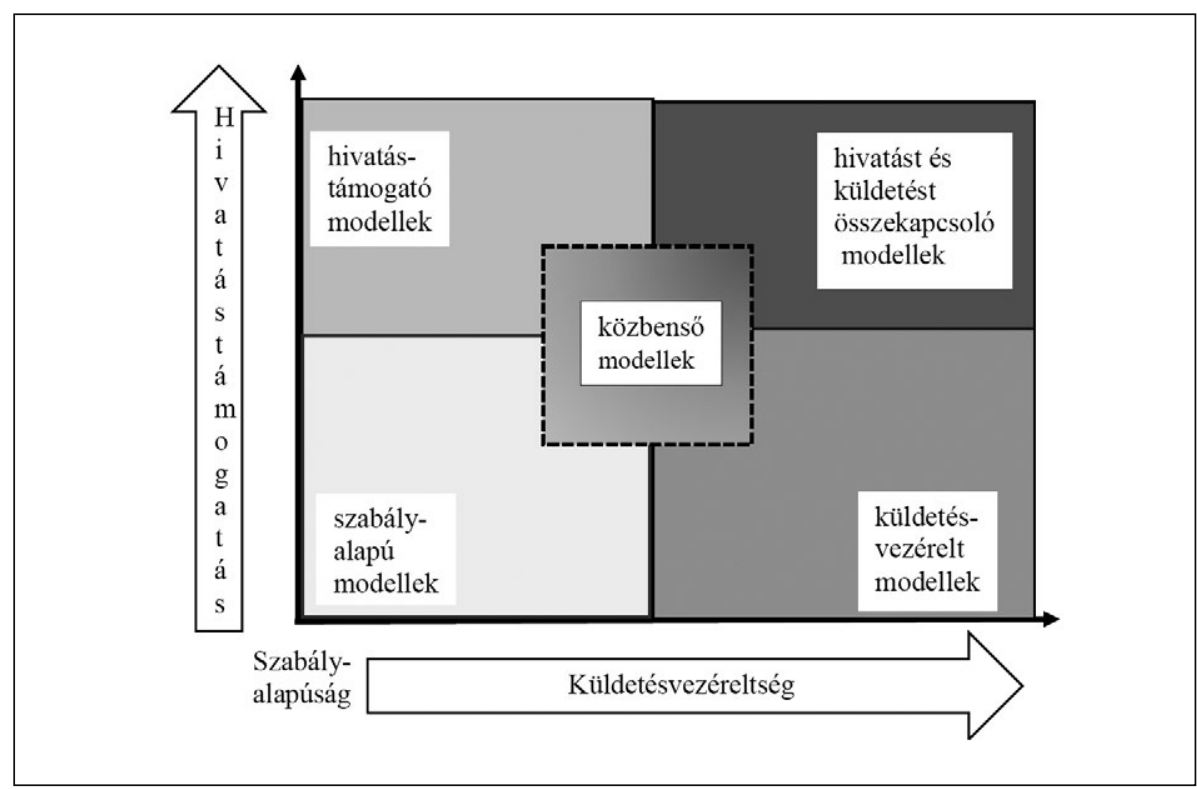

Forrás: A szerző saját szerkesztése

\section{Az integritásirányítási modell megválasztásának szempontjai}

A szervezeti kultúra két dimenziója mentén számos modellt lehet alkotni. Ezek szaporítása nem öncél. Olyan modelleket célszerü kidolgozni, amelyek a szervezet belső és külső szabályozási környezete figyelembevételével a szervezet integritását leginkább erősítik. Egy szervezet integritása végső soron azon múlik, hogy a tagjai (alkalmazottai) minden körülmények között követik-e a szervezet által kinyilvánított értékeket. A kérdés az, hogy a szervezet milyen modell mentén haladva képes leginkább elérni azt, hogy dolgozói minden körülmények között a szervezeti értékrendnek megfelelő döntést hozzanak. Ez nagy kihívás. Egyfelől azért, mert a dolgozók (pillanatnyi) érdekei ellentétesek lehetnek a szervezeti értékekkel (például nagy összegü vesztegetés elfogadása). Ilyenkor érdekkonfliktusról beszélhetünk. Másfelől azért, mert a dolgozók 
egyidejüleg több szerepet is betöltenek, következésképpen az egyéb szerepeik értékrendje ellentétbe kerülhet munkáltatójuk értékrendjével. Például az utóbbi tiltja a hivatali hatalommal való visszaélést, a vezető beosztású dolgozó mégis felhasználja hivatali befolyását ahhoz, hogy beteg édesanyja számára soron kívüli ellátást szerezzen, mivel számára a fiúi értékrend fontosabb, mint munkáltatója értékrendje. Az ilyen eseteket értékkonfliktusoknak nevezzük. Nagy erők hatnak abba az irányba, hogy a dolgozó a szervezeti értékrenddel ellentétesen cselekedjen, azaz integritássértést kövessen el.

Ilyen erőkkel szemben komoly ellenerőket, azaz kontrollokat kell felvonultatni, amelyek a kockázatot hordozó helyzetek kizárásától kezdve, a dolgozók magatartásának a monitorozásán és az integritássértések kemény szankcionálásán át, a helyes magatartáshoz adott útmutatásig, és az értékkövetés jutalmazásáig terjedhetnek. Az egyes eszközök önmagukban ritkán eredményesek. A kontrollok összehangolt rendszere az, amelynek révén a dolgozóknak a szervezeti értékek iránti elköteleződését arra a szintre lehet emelni, hogy kritikus döntési helyzetekben is a szervezeti értékeket tekintsék elsődlegesnek. E szempontból az egységes szervezeti kultúra azt a filozófiát jelenti, amelyek mentén az integritásirányítási rendszer különböző kontrolljait csatasorba állítják a szervezeti értékek érvényesülés érdekében.

Egy szervezet három módon kísérelheti meg elérni, hogy a dolgozója érdekeivel, illetve egyéb szerepeiből eredő értékeivel szemben a szervezet értékei kapjanak prioritást:

- megpróbálhatja kizárni a konfliktus lehetőségét (például összeférhetetlenség szabályozása, internet-hozzáférés letiltása);

- törekedhet olyan feltételeket teremteni, amelyek között a konfliktus feloldható (például családbarát munkarend alkalmazásával megkönnyíti a szülői és a munkavállalói szerepek értékeinek összeegyeztetését);

- fokozhatja a szervezeti értékek dominanciáját a dolgozói más értékeivel szemben (például az etikai kódex írásos elfogadtatása minden belépő dolgozóval).

Melyik a legjobb irány? Érdekkonfliktusok esetében az első irány a leghatásosabb, mivel nem sok sikerrel kecsegtet, ha erős érdekkel csak értékeket próbálunk szembeállítani. Ugyanakkor van helye a másik két irányú intézkedéseknek. A konfliktus feloldását jelentheti, ha a munkavállalók érdekérvényesítését csak addig a mértékig korlátozzák, amíg az ténylegesen ellentétes a szervezeti értékekkel. Ez alkalmazható például a mellékállások engedélyezésénél. Az értékek erőteljes kinyilvánításának érdekkonfliktusok esetében is lehet megelöző szerepe, mivel megnehezíti az értékrenddel ellentétes magatartás önigazolását. 
Értékkonfliktusok esetében is fontos eszköz a konfliktus lehetőségének kizárása, például annak lehetetlenné tétele, hogy az objektív rangsorokat bárki megváltoztathassa. Célszerü megpróbálkozni az értékkonfliktusok feloldásával is, hiszen egy munkavállaló számára nagy lelki terhet jelenthet az, ha más szerepeinek értékrendje folyamatosan ütközik a szervezeti értékrenddel. Például fontos szervezeti érték a pontos munkakezdés, de ennek kisgyerekes szülőként csak kínnal-keservvel tud eleget tenni. A rugalmas munkaidő viszont feloldaná a konfliktust. Ez egyúttal hozzájárulhat a szervezeti értékek dominanciájának elfogadásához is, mivel, ha a munkavállaló azt tapasztalja, hogy egyéb szerepei elvárásait a munkáltató legitimnek tartja, és megkönnyíti azok teljesítését, akkor munkáltatója értékeivel készségesebben azonosul.

A szervezeti értékek dominanciájának erősítése nemcsak azért fontos, mert ez az integritásközpontú megközelítésnek a lényege, hanem azért, mert csak ez képes a szervezeti integritással ellentétes magatartást megelőzni váratlan, nem szabályozott helyzetekben.

A három irányban is meghozott intézkedések - értelemszerüen - akkor a legeredményesebbek, ha egységes rendszert képeznek. Itt - az 1. számú ábrán bemutatott OECD integritás modelljét követve - célszerü megkülönböztetnünk a strukturális és a kulturális tényezőt. A strukturális tényezőt az integritásirányítási rendszer „technikai” létrehozása jelenti. A kulturális tényező abban mutatkozik meg, hogy a szervezeti kultúra a szabályalapúságtól mennyire mozdul el az értékkövetés két dimenziója mentén.

\section{Az integritásirányítás különböző szervezeti kultúrát tükröző modelljei}

E fejezetben az integritásirányításról szóló könyvem (Pulay, 2021) alapján felvázolok néhány kulturális szempontból nagyon különböző integritásirányítási modellt. Ezeket a 6. számú ábra a szervezeti integritás két dimenziója szerint kialakított koordináta rendszerben helyezi el. 
két dimenziója mentén elhelyezve

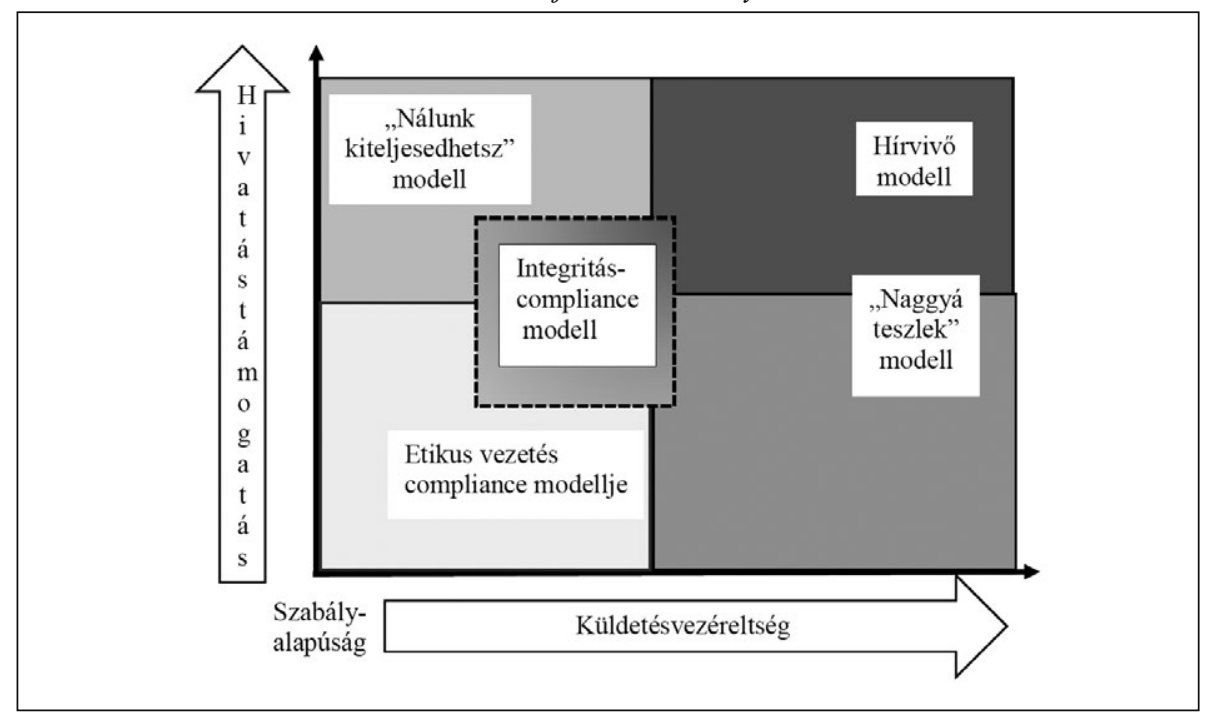

Forrás: A szerző saját szerkesztése.

A kiinduló pont a tiszta szabályalapúság, amely a belső szabályozások tökéletesítésével kívánja elérni, hogy a szervezet müködése minden rá vonatkozó szabálynak megfeleljen. Ez a hagyományos compliance (jogszabályi megfelelőségi) szemléletnek felel meg (Jancsó, 2019). Ezzel nem foglalkozok, mivel ebben a modellben nincs elmozdulás az értékkövetés felé.

Az etikus vezetés compliance modellje, amely az etikai normáknak történő megfelelést is célul tüzi ki (Ambrus \& Farkas, 2019; Kocziszky \& Kardkovács, 2020), eszközeit tekintve még szabályozásalapú, mivel az etikai megfelelést is elsősorban az etikai kockázatok feltárásával, és ezen újabb szabályozások (például részletes etikai és magatartási kódexek), eljárások (például etikai eljárások, panaszkezelési eljárások) bevezetésével próbálja elérni.

Újabb lépést jelent az értékközpontúság felé a nagy nemzetközi szervezetek által kidolgozott integritás - compliance - modell (Báger, 2019), amelynek célja az integritássértések megakadályozása olyan korszerü compliance módszerekkel, amelyek már magukban foglalják a vezetői példamutatást, az etikus szervezeti kultúra kialakítását és az integritási képzéseket is.

A 6.számú ábrán látható másik három modellt én dolgoztam ki, a gyakorlatban létező megoldások fő jellemzőinek tipizálása révén. A tipizálás - értelemszerúen - a különbségeket emeli ki, amelyek a gyakorlatban árnyaltabban, öszszetettebb módon nyilvánulhatnak meg. 
A „naggyá teszlek" modell esetén a szervezet vezetése arra törekszik, hogy dominánssá tegye a szervezeti értékeket, a dolgozóktól pedig elvárja, hogy teljes mértékben azonosuljanak ezen értékekkel, azaz a szervezeti értékek váljanak a dolgozók vezérlö értékévé. A modell mögött az a felismerés húzódik meg, hogy sok ember szeretne valami nemes dolgot véghez vinni, de egyedül nem találja az útját. Ekkor feltünik egy szervezet és azt hirdeti, hogy ő kiváló minőségü termékeket állít elö, vagy nagyszerü küldetése van, és aki csatlakozik hozzá, az részese lehet ennek a kiválóságnak. Természetesen csak akkor, ha teljes szívböl követi a szervezet értékeit és szabályait. A szervezethez csatlakozó egyén nemcsak egy jó munkahelyet kap, hanem büszkeséggel tölti el, hogy ő ehhez a szervezethez tartozik. A ,naggyá teszlek” modell a szervezeti integritás fenntartásának az egyik legeredményesebb modellje. Multinacionális vállalatok sokasága alkalmazza ezt. A hadseregek már évezredek óta használják e modellnek valamilyen változatát annak érdekében, hogy katonáik tüzön-vízen keresztül, saját életüket is bátran kockáztatva kövessék a hadsereg értékeit, és ennek révén a parancsokat.

E modell alkalmazásának előfeltétele, hogy a szervezet a legkiválóbbak közé tartozzon. Ennek híján a dolgozót nem tölti el büszkeség a munkahelyére gondolva. Fontos, hogy a szervezet egzisztenciális biztonságot, sőt folyamatos előrelépési lehetőséget tudjon nyújtani az értékeit követő dolgozói részére. Ez utóbbit szolgálják a fegyveres testületeknél a rendfokozatok. E modellben jól alkalmazhatók a szervezetnél eltöltött időt honoráló javadalmazási megoldások (életpályamodellek). A kiválóság a szervezethez kötődik, következésképpen a dolgozót a szervezethez való hüsége alapján jutalmazzák.

Dolgozóik azonosulását a szervezeti értékekkel az e modellt követő szervezetek hangzatos küldetésnyilatkozattal, az összetartást erősítő tréningekkel, közösségi programokkal segítik. Gyakran alkalmazzák a szervezeti kultúra szimbólumait. Számos pozitív ösztönzőt alkalmaznak, a szervezeti értékrenddel ellentétes magatartást viszont keményen szankcionálják.

E modell a közszférában is erősítheti a szervezeti integritást. A modell számos elemének a fegyveres testületeknél tiszteletre méltó hagyományai vannak, de a közszolgálat más területeinek életpályamodelljeit is lehetne ez irányba fejleszteni.

A „Nálunk kiteljesedhetsz” modellt választó szervezet olyan embereknek kínál kibontakozási lehetőséget, akiknek erős hivatástudata van. Ök a kiválóság személyes útját keresik, amit egy szintén kiválóságra törekvő szervezet tud felkínálni, azáltal, hogy megteremti számukra hivatásuk magas fokú kiteljesedésének feltételeit. $E$ modellben az egyén munkavállalói szerepe értékrendjének és egyéb szerepei értékeinek az ütközése esetén azért dönt a munkavállalói értékek követése mellett, mert ezek megegyeznek hivatása értékrendjével. 
E modell alkalmazásának terepét a tudásszervezetek jelentik, amelyek valódi kiválóságközponttá szeretnének és tudnak válni.

E modell megvalósításának a legfontosabb eszköze az, hogy a szervezet tartalmas, nagy felelősséggel járó feladatokat ad a munkavállalóknak. Emellett a dolgozó önfejlesztését támogatja. Belső szabályozása az önvezérlésre épít. Hangsúlyt helyez a személyes elszámoltathatóságra, és a nem teljesítést szankcionálja. E modell esetén a javadalmazást nem célszerủ a szervezetnél töltött időhöz kapcsolni, hanem a jövedelemnek az egyén kiválóságának mértékét kell tükröznie.

A szervezet vezetése bevonja a dolgozókat az őket érintő legfontosabb döntések előkészítésébe, a szervezeti értékrend kialakításába. A dolgozó könnyebben azonosul a szervezeti értékekkel, hiszen azokat ő maga is formálta. A szervezeti kultúra meghatározó értéke a kiválóságra törekvés, ami a dolgozónak is a legfőbb motivációja.

A „Hírvivő modell” akkor alkalmazható, ha a szervezetnek határozott küldetése van, a munkatárs pedig szeretné munkáját hivatásként végezni. A modell lényege a szervezet küldetésének és a munkatársak hivatásának az összekapcsolása. A hírvivő elnevezés onnan ered, hogy a hírvivő nem postás, aki átadja a bontatlan borítékot, és az abban levő hír a postás személyétől függetlenül lehet jó hír vagy rossz. Esetében a hír továbbadása nem szakítható el a hírvivő személyétől. A hírt csak akkor lehet eredményesen továbbadni, ha a hírvivő hiteles személy. Számos olyan tevékenység van, amelynek a minősége függ az azt végző személy hitelességétől. Ilyen minden személyes szolgáltatás, amely eredményesen csak akkor végezhető, ha az ügyfél megbízik a szolgáltatást nyújtó személyben. A „naggyá teszlek” modellben a munkavállaló integritása a szervezet integritását tükrözi, a „hírvivő" modellben a munkatárs integritása a szervezeti integritás hordozója.

A szervezet küldetése és munkatársai hivatása összekapcsolásának az előfeltétele az, hogy a szervezet kinyilvánított, a potenciális ügyfeleket és a munkatársakat egyaránt megszólítani tudó küldetéssel és értékrenddel rendelkezzen. E modellnél nagy szerepet kap a hírvivőnek alkalmas személyek kiválasztása.

A modell alapeleme a szolgáltatás és a szolgáltatást nyújtó személy összehangolt fejlesztése. Ennek érdekében a szervezetnek részletes stratégiával kell rendelkeznie küldetése megvalósításához, ami egyaránt tartalmazza a termék-, a szervezet- és a személyzetfejlesztési célokat, és ezek összeillesztésének eszközeit. A szervezet hangsúlyt fektet munkatársai képzésére, és figyelmet szentelnek arra, hogy a külső arculat kifejezze a belső tartalmat. E törekvés többnyire kiterjed a munkatársak megjelenésére is. A szervezet az etikai alapelvek meghatározásán túl, részletes magatartási kódexeket dolgoz ki, amely még az öltözékre is vonatkozik. 


\section{Összefoglalás}

A modellekről írtak remélhetőleg meggyőzőek voltak a tekintetben, hogy a szervezeti integritás megteremtése és fenntartása szempontjából egyáltalán nem mindegy, hogy a szervezet milyen integritási filozófiát választ, és azt milyen egymással harmonizáló, egymás hatásait felerősítő, illetve kiegészítő eszközök révén valósítja meg. A megfelelő integritási modell megtalálása a kiválóságra törekvés szempontjából fontos. Kiválóság nem képzelhető el anélkül, hogy a szervezet vezetői és munkatársainak többsége ne köteleződne el a szervezet értékei mellett. A három általam felvázolt modell a kiválóság három alapesetét különbözteti meg. A „naggyá teszlek” modellben a szervezet a kiváló, és ezt sugározza ki munkavállalóira. A „nálunk kiteljesedhetsz” modellben az egyén törekszik a kiválóságra, aki teljesítményével hozzájárul a szervezet kiválóvá válásához. A „hírvivő” modellben a kiválóság a szervezet és a munkatársak értékrendjének összehangolása révén érhető el. Nem mindegy az sem, hogy az elérni szándékozott kiválóság termékekben, intellektuális szolgáltatásokban vagy személyes szolgáltatásokban ölt testet. Ezért valóban célszerü elemezni, hogy a közszféra különbözö típusú szervezeteinél milyen integritási modell tud leginkább hozzájárulni az integritás megszilárdításához, a kiválóság eléréséhez.

\section{Felhasznált irodalom}

Ambrus I. \& Farkas Á. (2019). A compliance alapkérdései - Az etikus vállalati müködés elmélete és gyakorlata. Wolters Kluwer.

Báger G. (2019). Az integritás, mint az irányítás új szemlélete és eszköze. In Parragh B. (Szerk.), Ösztönzö állam - hatékonyabb vállalatok (pp. 187-217). Akadémiai Kiadó.

Báger G., Korbuly A. \& Pulay Gy. (2008). Korrupciós kockázatok feltérképezése a magyar közszférában. Állami Számvevőszék.

Boland, M. (2015). Integrity management - a model for effective implementation. The APPEA Journal, 55(2), 483-483. https://doi.org/10.1071/AJ14118

Domokos L., Pulay Gy., Gergely Sz. \& Szabó Z. Gy. (2015). Az integritás kultúrájának meghonositása a magyar közszférában. Állami Számvevőszék.

Jancsó J. (2019). A compliance fogalmáról és szerepéről a gazdasági életben. Miskolci Jogi Szemle, 14(1), 82-91.

Kocziszky Gy. \& Kardkovács K. (2020). Compliance szerepe a közösségi értékek és érdekek védelmében - Elmélet és gyakorlat. Akadémiai Kiadó. https://doi.org/10.1556/9789634545972

Klotz P. \& Sántha Gy. (2013). Törzsanyag az „Integritásmenedzsment” címü tantárgyhoz. Nemzeti Közszolgálati Egyetem Vezető- és Továbbképzési Intézet. 
Kritikus Rendszerek Kutatócsoport (2021). Modellezés és metamodellezés. Budapesti Müszaki és Gazdaságtudományi Egyetem. https://ftsrg.mit.bme.hu/remo-jegyzet/modellezes-es-metamodellezes.pdf

Lander, N. \& Nahon, D. (2006). The Integrity Model of Existential Psychotherapy in Working with the 'Difficult Patient. Routledge. https://doi.org/10.4324/9780203098691

Organisation for Economic Co-Operation and Development (2009). Towards a Sound Integrity Framework: Instruments, Processes, Structures and Conditions for Implementation. OECD.

Organisation for Economic Co-Operation and Development (2017). Recommendations on Public Integrity - A Strategy against Corruption. https://www.oecd.org/gov/ethics/integrity-recommendation-hu.pdf

Pulay Gy. (2017). Integritásközpontú vezetés. In Bábosik M. (Szerk.), Vezetés a közjó szolgálatában - Közpénzügyi gazdálkodás és menedzsment (pp. 157-190). Typotex Kiadó.

Pulay Gy. (2021). Integritásmenedzsment - A bizalom megteremtése és megörzése. Akadémiai Kiadó. https://doi.org/10.1556/9789634546320

\section{Online hivatkozások}

URL1: Eurosai Task Force on Audit and Ethic (2017). Audit of Ethics in Public Sector Organisations. Guideline. http://www.eurosai-tfae.tcontas.pt/activities/

\section{Alkalmazott jogszabályok}

1328/2020. (VI. 19.) Korm. határozat a 2020-2022 közötti időszakra szóló középtávú Nemzeti Korrupcióellenes Stratégia, valamint az ahhoz kapcsolódó intézkedési terv elfogadásáról 50/2013. (II. 25.) Korm. rendelet az államigazgatási szervek integritásirányítási rendszeréről és az érdekérvényesítők fogadásának rendjéről

370/2011. (XII. 31.) Korm. rendelet a költségvetési szervek belső kontrollrendszeréröl és belső ellenőrzéséröl

187/2016. (VII.13) Korm. rendelet egyes kormányrendeleteknek a belső kontrollrendszer és az integritásirányítási rendszer fejlesztésével összefüggő módosításáról

339/2019. (XII. 23.) Korm. rendelet a köztulajdonban álló gazdasági társaságok belső kontrollrendszeréröl

2009. évi CXXII. törvény a köztulajdonban álló gazdasági társaságok takarékosabb működéséről

\section{A cikk APA szabály szerinti hivatkozása}

Pulay Gy. (2021). Az integritásirányítás lehetséges modelljei. Belügyi Szemle, 69(11), 19011920. https://doi.org/10.38146/BSZ.2021.11.2 